\title{
Langerhans cell histiocytosis with intrathymic calcifications and cavitation
}

\author{
Alexis J. Crawley • R. Paul Guillerman
}

Received: 30 July 2010 /Revised: 25 September 2010 /Accepted: 28 September 2010 /Published online: 10 October 2010

(C) Springer-Verlag 2010

A 3-month-old boy presented with respiratory distress, cough, poor feeding and a mediastinal mass on a chest radiograph. A CT scan of the chest demonstrated diffuse thymic enlargement with punctate intrathymic calcifications (Fig. 1) and cavitation (Fig. 2). A diagnosis of Langerhans cell histiocytosis $(\mathrm{LCH})$ was suggested based on the CT findings and confirmed by biopsy of a skin rash.

Granulomatous infiltration of the thymus by dendritic cells is common in pediatric $\mathrm{LCH}$, especially in multisystem

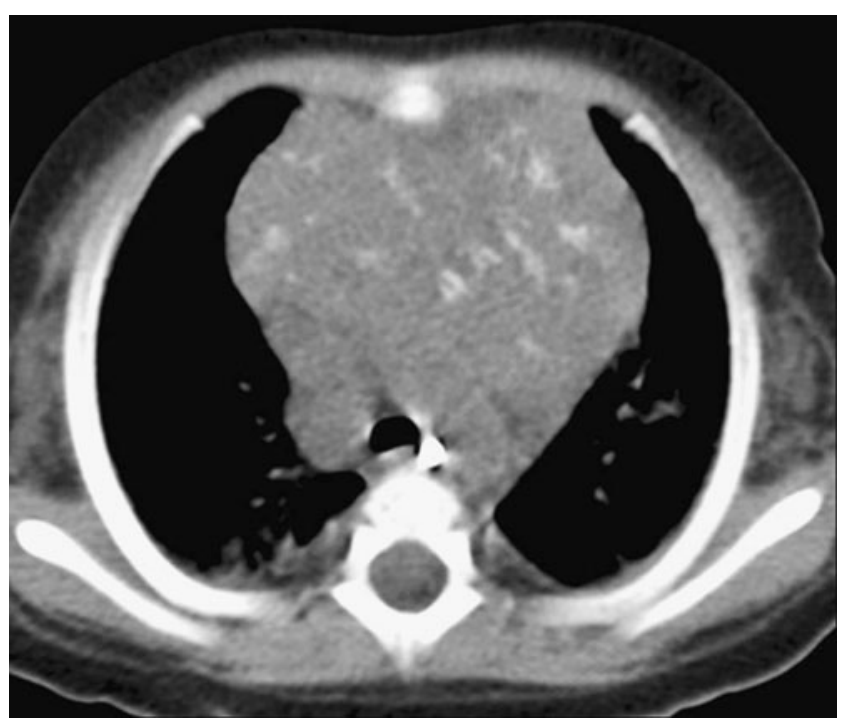

Fig. 1 Chest CT image at soft-tissue windows

\section{A. J. Crawley}

Baylor College of Medicine,

Houston, TX, USA

R. P. Guillerman $(\bowtie)$

Department of Pediatric Radiology, Texas Children's Hospital,

Baylor College of Medicine,

6621 Fannin CC470.01,

Houston, TX 77030, USA

e-mail: rpguille@texaschildrens.org disease, and results in the formation of an anterior mediastinal mass. The differential diagnoses of an anterior mediastinal mass in children include thymic hyperplasia, germ cell neoplasia, T-cell leukemia, lymphoma, granulomatous disease and LCH. Although uncommon, the presence of punctate calcifications [1] and cavitary air cysts [2] in an enlarged thymus are highly specific for LCH. In addition to thymic involvement, chest imaging may reveal reticulonodular pulmonary opacities, lung cysts or lytic bone lesions.

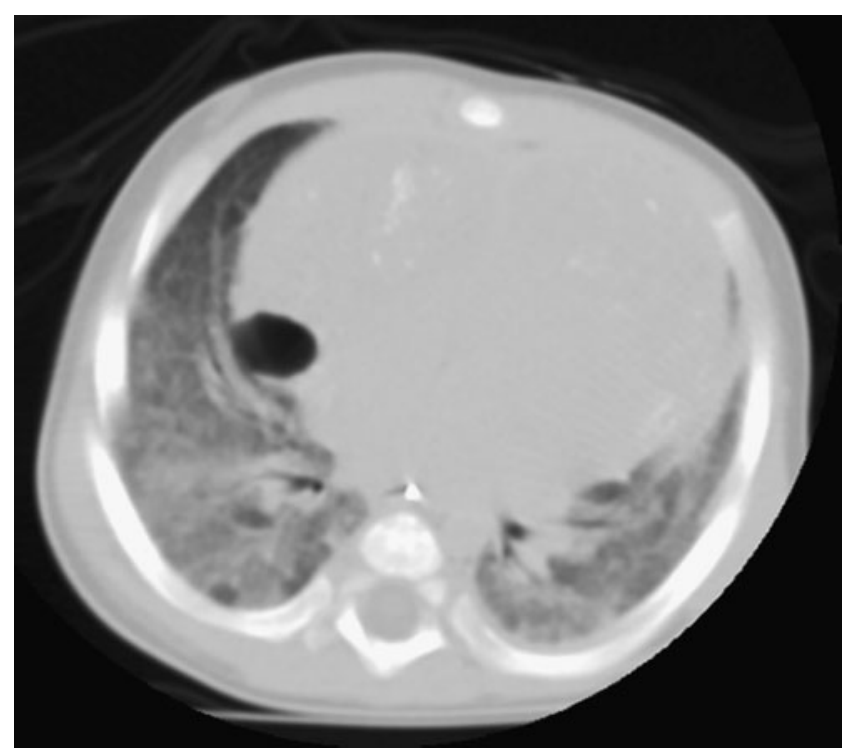

Fig. 2 Chest CT image at lung windows

\section{References}

1. Heller GD, Haller JO, Berdon WE et al (1999) Punctate thymic calcification in infants with untreated Langerhans' cell histiocytosis: report of four new cases. Pediatr Radiol 29:813-815

2. Abramson SJ, Berdon WE, Reilly BJ et al (1987) Cavitation of anterior mediastinal masses in children with histiocytosis-X. Pediatr Radiol 17:10-14 